28. A Review of the Cetacea of the New Zealand Seas.-I. By W.R. B. Oliver, F.L.S., F.Z.S., Dominion Museum, Wellington, N.Z.

[Received May 18, 1922 : Read June 13, 1922.]

\title{
(Plates I.-IV.*)
}

Except the popular accounts by Waite, and by Hutton and Drummond, no general list of the New Zealand Cetacea has been published since Hector's paper on the Delphinidre in 1887. Having a number of notes made on various occasions to put on record, I take the opportunity of reviewing the Whales and Dolphins of our seas. The recorded knowledge of the group is very incomplete; and, moreover, some errors are apparent. The museums at Wellington and Christchurch contain a fair number of skeletons; those of Dunedin and Wanganui fewer. The only representatives of the Cetacea in the Auckland Museum appear to be three skulls. The specimens in Christchurch and Dunedin have, in the main, been recorded, but in Wellington and Wanganui there are some skeletons of considerable interest which have not hitherto been described. These are mentioned in the present paper. Besides cataloguing the specimens in the principal museums in New Zealand, I have included those specimens from New Zealand that I have been able to trace in the museums of Australia, America, and Europe. Many of these I have examined. The short descriptions given with the lists refer mainly to variable characters; and, where I myself have not examined the specimen, the author from whom I have quoted is given. An attempt has also been made to give the generic and specific names in accordance with the International Rules of Zoological Nomenclature. The literature on the Cetacea is very extensive, but some of it has to be used with caution. This applies to many of the writings of Dr. J. E. Gray, who unfortunately gave new names on quite insufficient grounds, sometimes founding genera and species on drawings and photographs he appeared not to understand. I have quoted only the principal references, including those where new names are proposed or where there are descriptions based on specimens.

I cannot claim to have added a single species to the list of New Zealand cetaceans; on the contrary, I have omitted two, Delphinapterus leucas and Hyperoodon planifrons, and hope that the evidence that neither belongs to our fauna will be accepted.

It will appear from the following account that there is much to be learned about the distribution and habits of the cetaceans of our seas; moreover, collection of perfect skeletons and descriptions of the external characters of the animals is much to be desired. In some cases the species are only known from skulls or skeletons.

\footnotetext{
* For explanation of the Plates, see p. 585.
} 
It is hoped, therefore, that the present paper will be found useful in bringing together what is known on the subject, so that the gaps in our knowledge may be filled up. A great deal of information could be gained if, when a whale or dolphin is stranded, a description and, if possibie, a photograph were sent to the nearest museum. By this means the animal might be correctly identified, and if belonging to a rare species, steps might be taken to preserve the skeleton.

For supplying lists of specimens in the institutions under their charge, I have to thank the Director, British Museum (Natural History), London, the Secretary, United States National Museum, Washington, D.C., and the Director, Muséum d'Histoire Naturelle, Paris.

\section{BaLæNa.}

Balcena Linné, 1758, Syst. Nat. ed. 10, p. 75 ; type, B. mysticetus L. Eubalcena Gray, 1864, Proc. Zool. Soc. 1864, p. 201 ; type, Balcena australis Desmoulins. Caperea Gray, 1864, l.c. p. 202 ; type, Balcena antipodarum Gray.

\section{BaLena australis.}

Balcena australis Desmoulins, 1822, Dict. Class. Hist. Nat. vol. ii. p. 161 (Cape of Good Hope); Waite, 1909, Subant. Is. N.Z. vol. ii. p. 549. Balcence antipodum Gray, 1843, in Dieffenbach's Travels in N.Z. vol. ii. p. 183 (New Zealand), pl. 1, lettered B. antipodarum. Caperea antipodarum Gray, 1866, Cat. Seals \& Whales Brit. Mus. p. 101 ; Proc. Zool. Soc. 1873, p. 143. Balcena antipodarum Gray, Dieffenbach, Travels in N.Z. vol. i. p. 44; Van Beneden \& Gervais, 1880, Ostéogr. Cet. p. 46, p]. 3. Eubalcena australis Desm., Hector, 1872, Trans. N.Z. Inst. vol. v. p. 156 ; id. 1878, l. c. vol.x. p. 333. Balcena hectori Gray, 1874, Ann. Mag. Nat. Hist. ser. 4, vol. xiii. p. 56. Macleayius australiensis Gray, 1873, Ann. Mag. Nat. Hist. ser. 4, vol. xi. p. 75 ; id. Proc. Zool. Soc. 1873 , p. 130 ; id. 1874 , Trans. N.Z. Inst. vol. vi. p. 90 , pls. 16,17 .

The Southern Right Whale, which is confined to the South Temperate and Subantarctic Oceans, appears to differ from the Nordcaper (B. glacialis) in the number of ribs and other ostenlogical features. It was formerly very abundant in the New Zealand seas, but has been almost exterminated by whalers. During the first half of last century immense numbers were killed, and of these usually more than haif were lost (see Hocken, Proc. N.Z. Inst. vol. iii. p. 69, 1871). The females visited the bays to calve during the months of May, June, and July, and during this period both the cows and calves were killed. Later in the season the whaling-vessels cruised in the "off-shore grounds." Whalingstations are at present established at Picton and Kaikoura, motorlaunches being engaged for procuring the whales. Five Right Whales were brought into Picton in 1915-16 and one in 1917; from the Kaikoura station three were killed in 1917-18. A 
whaling-station was formerly established at Campbell Island. Waite states that Right Whales are nearly always seen during the southern cruise of the Government vessels.

Cook Strait.--(a) Dieffenbach describes and figures (vol. ii. pl. 1) a Right Whale, stranded in Jackson's Bay, Tory Channel, in 1839. On this figure, Gray in the same work founded Balcence antipodum; the plate, however, was lettered Balcena antipodarum. The tympanic bone later referred to this species (Gray, 1866) belonged to Neobalana marginata. Caperea was founded on B. antipodarum, and the tympanic bone mentioned. (b) Tory Channel. Scapula in Dominion Museum. Described by Gray as Balcena hectori. Acromion distinct.

Canterbury.-(a) Skeleton in British Museum sent by von Haast. Described by Gray ( $M$. australiensis). Vertebræ 54. Cervicals and first dorsal fused into one mass by their centra. Sternum oblong, $6 \frac{1}{2} \times 5$ in. Scapula with broad compressed acromion. (Gray.) (b) Akaroa Harbour. Skeleton with baleen in the Paris Museum. Taken by Berard and Arnoux, of the French corvette, 'Le Rhin.' Described by Van Beneden and Gervais, and by Hector (1878). Vertebræ: C. 7, D. 15, L. 11, Ca. $21=54$. Cervicals fused. Scapula with acromion represented only by a ridge. Phalanges : $2,5,6,5,4$. Distal end of first rib expanded and two-headed. Sternum triangular, sinuated, sides convex, articular facets at front angles. (From van Beneden and Gervais's description and figure.) Van Beneden in two places states the total number of vertebræ to be 53, but figures for each portion of the vertebral column are also given as above stated.

Otago.-Skeleton with baleen in the Otago Museum. Described by Hector (1878). Young specimen 29 feet long. Vertebræ : C. 7, D. 14, L. 11, Ca. 22=54. Six cervicals united by their centra. Caudal region imperfect. Ribs 14. Scapula with a welldeveloped narrow acromion. (Hector states that the dorsals number 15 , and the ribs should probably be 15.)

\section{Neobalena.}

Neobalcena Gray, 1870, Ann. Mag. Nat. Hist. ser. 4, vol. vi. p. 155; type, Balcena marginata Gray.

\section{Neobalana marginata. (Pl. I.)}

Belcena marginata Gray, 1846, Zool. 'Erebus' \& 'Terror,' p. 48, pl. 1 (West Australia). Balcena antipodarum Gray, 1864, Proc. Zool. Soc. p. 202 (tympanic bone). Balana marginata Gray, Hector, 1870, Trans. N.Z. Inst. vol. ii. p. 26, pl. $2 b$; id. 1870, Ann. Mag. Nat. Hist. ser. 4, vol. v. p. 221. Neobaloena marginata Gray, 1870, Ann. Mag. Nat. Hist. ser. 4, vol. vi. p. 156 ; id. 1873 , l. c. vol. xi. p. 108 ; id. 1871 , Trans. N.Z. Inst. vol. iii. p. 123 ; id. 1874 , l. c. vol. vi. p. 93. Hector, 1873, Trans. N.Z. Inst. vol. v. p. 155 ; id. 1875 , 1. c. vol, vii. p. 271 , pls. 16,17 ; id. 1878 , 1. c. vol. x. p. 331 . 
The Pigmy Right Whale has occurred a number of times on the New Zealand coast. Elsewhere it has been recorded from West Australia and South Australia. Balcena marginata was founded on three plates of baleen now in the British Museum. A skull from Kawau was next recognized as belonging to the same species, and was described by Hector $(1870$, p. 26). This was constantly referred to by Hector and others (see Palmer, Index Gen. Mamm. p. 452, 1904) as the "type" of the species, but this is obviously wrong. The type of Balcena marginata is the baleen from West Australia in the British Museum.

Kawau.-Skull in Dominion Museum, Wellington. Described by Hector (1870). Hector afterwards referred to this as the type skull. On Hector's description Gray separated the species from Balcena under the generic name Neobalcena. (Pl. I. figs. 2 \& 3.)

Oharia, Cook Strait.-Skeleton in Dominion Museum, Wellington. Vertebræ: C. 7, D. 18, L. 2, Ca. 14=41. Cervicals fused. Ribs 17 , of which 2 nd to 5 th are two-headed.

Canterbury Coast.- Skeleton in Australian Museum, Sydney.

Stewart Island.-(a) Skeleton with baleen in British Museum. Described by Hector $(1875,1871)$. In this description the number of vertebræ and ribs appears to be incorrectly stated. Compare the description by Beddard ('Book of Whales,' p. 141, 1900.) (b) Skeleton in Dominion Museum, Wellington. Skull symmetrical. Viewed from above, the general form is triangular, broadest behind where at the angles the supraoccipital and squamosals meet; from here it tapers at first gradually to the edge of the orbits, then suddenly to opposite the nasals; thence follows a long, tapering, pointed rostrum with slightly concave sides. Viewed from the side, the upper contour of the skull is nearly straight from condyles to vertex, then depressed at a broad angle and slightly bowed to the tip of the rostrum. Premaxillaries narrow, of nearly uniform width, their inner edges meeting as an acute ridge in front, but flattening out near the blow-hole and twisting so that the outer edges form ridges each side of it. Maxillaries broad behind, suddenly contracting to opposite the nasals, tapering to a point anteriorly, not extending as far forward as the premaxillaries. The exposed lateral portions of the frontal form two bread quadrangular plates, overlapping. the posterior portion of the maxillaries, and well below the level of the supraoccipital, slightly concave centrally, but arched over the orbits. A narrow strip only of the frontal exposed between the supraoccipital and nasals. Wide deep lateral channels between upper and lower horizontal expansions of the supraoccipital. On the palatal aspect of the skull the maxillaries form a sharp central ridge, between which the vomer is exposed. Pterygoids meeting along the middle line, flat behind but anteriorly forming a ridge continuous with that of the maxillaries. Rami of mandible massive, compressed, angled above and below ; nerve foramina near the upper edge. (Pl. I. fig. 1.) Vertebræ: C. 7 , D. 18 , L. 1 , Ca. $14=40$. Cervicals fused into a single mass. 
by their centra and neural arches. Spinous processes forming a high acute vertical ridge; posteriorly the sides of the neural arches project as laminated plates. Seven nerve foramina on each side. Anteriorly there is a large vertical lateral process with three projecting knobs in a vertical line and a fourth behind the upper one. The first dorsal has a forwardly-directed spinous process, short-pointed transverse processes, and bears no ribs. Transverse processes in the second dorsal angular, in the third and fourth wider and twisted, in the remainder very broad and flat, with the anterior sides projecting considerably in advance of the centra. Articular facets on the distal ends of the transverse processes of the $2 \mathrm{nd}$ to 10 th dorsals. Spinous processes broad and flat, with lamellar metapophyses from the third dorsal backwards. Lumbar vertebræ similar to last dorsal ; the transverse processes longer in an antero-posterior than in a transverse direction. The first seven caudals bear chevrons. Transverse processes reduced to ridges on the fifth, last neural canal evident on the 8th caudal, which is the last of the compressed form. In all the vertebræ behind the cervicals, the epiphyses are marked by distinct sutures. Ribs 17, articulated to the 2nd to 18th dorsals. First singleheaded, broad and truncate distally, 2nd to 5th double-headed, but the capitula not reaching the centra. Remainder single-headed, with very broad, flat blades, except the last two pairs, which are small and narrow. The last twelve ribs are set at nearly a right angle to the transyerse processes of the vertebræ. Scapula much wider than long, flat with a very slight spine; acromion directed forwards, flat, moderately broad, and tapering; coracoid short and narrow. Sternum shield-shaped, notched in front, one articular facet on each side for the first rib.

Locality not known.-(a) Skull of young in Auckland Museum. Described by Hector (1875). (b) There is a skeleton or portion of one in the Paris Museum sent by Mr. Trail in 1879. It probably came from Stewart Island.

\section{BALANOPTERA.}

Balcenoptera Lacépède, 1804, Hist. Nat. Cét. pp. xxxvi. 114 ; type, B. acuto-rostrata Lacép.

To the four recent species constituting this genus, 18 generic names have been applied. Of these, eight were founded by Dr. J. E. Gray, whose prolific writings on the Cetacea resulted in more synonyms than valid names, and are the despair of later students.

\section{Balenoptera musculus.}

Balcena musculus Linné, 1758, Syst. Nat. ed. 10, p. 76 (Scotland) (not Balcenoptera musculus auct.). Balcenoptera sibbaldii Gray, 1847, Proc. Zool. Soc. 1847, p. 92 ; Waite, 1912, Rec. Cant. Mus. vol. i. p. 333, pls. 69-71; id. 1912, Guide Whales \& Dolph. N.Z. p. 10, pls. 1-3. Balcenopterce musculus Linné, Waite, 1909, Subaṇt. Is. N.Z. vol. ii. p, 550 . 
The Blue Whale, which has a very wide range and is exceedingly abundant in the Antarctic Ocean, has only once been recorded with certainty on the New Zealand coast.

Okarito.-Skeleton in the Canterbury Museum. The dead whale came ashore near Okarito in February 1908. Described by Waite. Vertebæ: C. 7, D. 15, L. 14 , Ca. $28=64$. Cervicals free. Ribs 15, 2nd to 5th two-headed. Transverse processes of first lumbar vertebræ with articular surfaces. Sternum $56 \mathrm{~cm}$. long, with five processes; one posterior, long; two lateral, triangular; two anterior diverging, truncate. Pelvic bones about $30 \mathrm{~cm}$. in length, posteriorly bent downwards at nearly a right angle, each with a small detached bone about $2 \mathrm{~cm}$. long above. Phalanges: $0,7,8,8,5$.

Coal Point, Otago.-A large whale came ashore here in 1873. Some plates of baleen only were preserved, and were described by Hutton (Trans. N.Z. Inst. vol. vii. p. 266, 1875). They probably belonged to this species.

\section{BALENOPTERA PHYSALUS.}

Balcena physalus Linné, Syst. Nat. ed. 10, p. 75 (European seas) (Balcenopterca musculus auct.). Physalus australis Desm., Hector, 1875, Trans. N. Z. Inst. vol. vii. p. 257, pl. 18; id. 1878, l. c. vol. x. p. 336. Balcenopterca australis Desm., von Haast, 1883, Proc. Zool. Soc. 1883, p. 592. Balcenoptera musculus (not Linné) Parker, 1885, Trans. N.Z. vol. xvii. p. 3, pl. 6. Stenobalcena xanthogaster Gray, 1874, Ann. Mag. Nat. Hist. ser. 4, vol. xiv. p. 305 ; “Sulphur-bottom," Hector, 1874, Ann. Mag. Nat. Hist. ser. 4, vol. xiv. p. 304.

This is the common Finner of both northern and southern seas. It is occasionally cast ashore on the New Zealand coast.

Nelson.-Stranded at entrance of Waimea River, 1883. Skeleton in Otago Museum. . Described by Parker. Vertebræ: C. 7 , D. $15, \mathrm{~L} 15, \mathrm{Ca} .25=62$. Ribs 15 , of which $2 \mathrm{nd}$ and $3 \mathrm{rd}$ are two-headed, last rib less than half the length of the one in front. Sternum with posterior process longer than the lateral ones. Baleen slate-colour with white fibres.

Cook Strait.--Stranded at Port Underwood, 10th June, 1874. Skeleton in Dominion Museum, Wellington. Described by Hector. On Hector's description Gray founded the genus and species Stenobalcenc xanthogaster. Vertebræ: C. 7, D. 15, L. 15, Ca. $25=62$. Ribs 15, of which 2 nd and 3rd are two-headed. Sternum with posterior process shorter than laterals.

New Brighton Beach.-Stranded 1881. Skeleton described by Haast. Vertebræ: C. 7, D. 15, L. 15, Ca. 25=62. Pelvic bone 13 in. long, 6 in. broad. Sternum with the posterior process. shorter than the laterals. (Von Haast.)

BALANOPTERA BOREALIS.

Balcenoptera borealis Lesson, 1828, Hist. Nat. Cet. p. 342; Lillie, 1915, 'Terra Nova' Exped., Zool. vol. i. p. 117, pl. 7. 
The Sei Whale does not appear to be common south of the Equator. The following are the only known occurrences of the species in New Zealand waters:-

Off Bay of Islands.--(a) Exterior described by Lillie. Baleen black, with fine greyish-white bristles. (b) A male specimen, $14 \mathrm{~m}$. long, was brought into the whaling-station at Whangamumu during my visit on the 5th December, 1911. It had been harpooned, the weapon passing right through the body and exploding in the water. Colour above slate, sides mottled, below silvery white; iris dark brown; baleen dark slate, upper inner angle streaked longitudinally with lighter, bristles white. Dorsal fin falcate. Flipper with lower edge nearly straight, upper rounded. Plaits between the fins 60,7 or 8 more on each side behind the eye. Plaits begin about $25 \mathrm{~cm}$. from the tip of flipper and anterior edge of fin. Contour of back nearly straight, suddenly depressed in front of flukes. Hairs on lower jaw in two rows; inside row with 12 on right side, 13 on left; outside row 1 on right, 2 on left side; total, 28 hairs. There are some punctures behind the hairs, and others in front of the body-plaits. Measurements: Total length, $14 \mathrm{~m}$; snout to anterior edge of flipper, $3.80 \mathrm{~m}$.; snout to anterior edge of dorsal fin, $9.40 \mathrm{~m}$.; height of fin, $40 \mathrm{~cm}$.; length of upper edge of flipper, $115 \mathrm{~cm}$.; its width, $38 \mathrm{~cm}$.; height of body, about $180 \mathrm{~cm}$. Baleen plates, 11.5 to $12.5 \mathrm{~mm}$. apart; length of front plates, $8 \mathrm{~cm}$., of longest $34 \mathrm{~cm}$. The mouth was filled with small crustaceans. The colours noted above were taken shortly after the whale was killed, and are lighter than those usually recorded. Lillie makes a similar observation.

Cook Strait.-During a heavy gale at the end of January 1922, the carcase of an adult female of the Sei Whale floated through the entrance of Porirua Harbour and stranded opposite Paremata. It measured 53 feet in length. It had been dead some time, and caused a good deal of consternation among residents of the locality. The carcase was subsequently towed to sea and cast adrift.

\section{BALFNOPTERA ACUTOROSTRATA.}

Balcenoptera acutorostrata Lacépède, 1804, Hist. Nat. Cét. vol. i. p. 197 ; Lillie, 1915, 'Terra Nova' Exped., Zool. vol. i. pls. 4, 5. Balcenoptera rostrata Fabricius, von Haast, 1881, Trans. N.Z. Inst. vol. xiii. p. 169, pl. 3 ; Benham, 1901, Proc. Zool. Soc. 1901, vol. i. p. 278; id. 1902, Trans. N.Z. Inst. vol. xxxiv. p. 151. Balcenoptera huttoni Gray, 1874, Ann. Mag. Nat. Hist. ser. 4, vol. xiii. p. 450 ; Hector, 1878 , Trans. N.Z. Inst. vol. x. p. 337. Physalus antarcticus Gray, 1874, Ann. Mag. Nat. Hist. ser. 4, vol. xiii. p. 316.

The Pike Whale, like its congeners, is widely distributed All the records certainly identified from New Zealand have been from the South Island. In addition to the following specimens,

Proc. Zool. Soc.-1922, No. XXXIX. 
however, a young Pike Whale was recorded as having been killed at Port Ahuriri, Hawke's Bay, in 1885. Variations occur with regard to the vertebral formulæ. Apparently the normal number is C. 7, D. $11, \mathrm{~L} .13$, Ca. $17=48$.

Sumner, Canterbury.--Stranded 7th February, 1880. Skeleton in Canterbury Museum. Described by von Haast. Vertebræ: C. 7 , D. 11 , L. 12 , Ca. $18=48$. Ribs 11 . Sternum longer than broad. Pelvic bones rod-shaped, about $22 \mathrm{~cm}$. long.

Moeraki.-1885. Skull (incomplete) in Otago Museum.

Otago Heads.-(a) Oct. 1873. Skeleton with baleen in British Museum. Described by Gray as the type of Balcenopterca huttoni. Measurements given by Gray (p. 45i). Vertebræ: C. 7 , D. 12 , L. 13 , Ca. $16=48$. Ribs 11. (Gray.) (b) Young female cast ashore, August 1900. Exterior described by Benham (1902). Larynx described by Benham (1901). Animal figured by Lillie.

Locality not stated.- Skeleton in Dominion Museum, Wellington. Vertebræ: C. 7, D. 11, L. 13, Ca. $17=48$. Cervicals : 2nd and 3rd fused by neural arch on right side; 4th and 5th separately fused by distal ends of upper lateral precesses on right side; otherwise free. Atlas with short transverse processes; 2 nd to 5 th with both upper and lower transverse processes ; 6th and 7 th with upper transverse processes only. The 8th caudal bears the last spinous process and the last complete neural canal. Ribs 11. Sternum with the length about $4 \mathrm{~mm}$. short of the breadth; posterior process long and of nearly even width. Scapula with long acromion widening towards the distal end; coracoid thick, less than half the length of the acromion.

\section{Megaptera.}

Megaptera Gray, 1846, Zool. 'Erebus' \& 'Terror,' Mamm. p. 16 ; type Balana longimana Rudolphi (=B. nodosa Bonnaterre).

\section{Megaptera Nodosa.}

Balcena nodosa Bonnaterre, 1789, Tabl. Encyl. Méth., Cét. p. 5 (New England, U.S.A.); Lillie, 1915, 'Terra Nova' Exped., Zool. vol. i. pp. 87-110, pls. 1-4. Megaptera novce zeculandice Gray, 1864, Proc. Zool. Soc. 1864, p. 207 ; id. 1866, Cat. Seals \& Whales Brit. Mus. p. 128, fig. 20; Hector, 1873, Trans. N.Z. Inst. vol. v. p. 156 ; id. 1875 , l. c. vol. vii. p. 255 ; Van Beneden \& Gervais, 1880, Ostéogr. Cét. p. 135 ; Gray, 1874, Ann. Mag. Nat. Hist. ser. 4, vol. xiii. p. 57. Megaptera lalandii Fischer, von Haast, 1883, Trans. N.Z. Inst. vol. xv. p. 214 ; Hector, 1878, l. c. vol.x. p. 335. Megaptera boops (not Linné) Oliver, 1911, Trans. N.Z. Inst. vol. lxiii. p. 536.

The Humpback is the most common whale frequenting the New Zealand seas, but no skeleton of an animal caught within this area has been adequately described. A satisfactory description, however, has been given by Lillie of the external and internal 
features from specimens brought into the Whangamumu whalingstation.

Humpback Whales regularly migrate, spending the southern summer south of New Zealand and the winter in subtropical seas. They appear at the Kermadec Islands in the latter part of August, but are most common in the group during October and November. They have their calves with them at this time. They appear off the Bay of Islands in the latter part of September, the main body passing southwards during October and November. By the middle of December no more are to be seen here. From this time until April they appear to be absent from New Zealand waters. They are hunted in Cook Strait from May to August, and appear off the Bay of Islands between the middle of April and the end of August, but are not seen at the Kermadec Islands until later in the year, as noted above. (Lillie; Oliver.)

Kermadec Islands. - Frequent the group in large numbers with their calves from middle of August to end of November.

Chatham Islands.-Baleen in the Canterbury Museum.

Off Cape Brett.- - Regularly shot by harpoon-gun from small steam-vessel and brought into the Whangamumu whaling-station. The yearly catch varies between 40 and 70 . The exterior and anatomy have been well described by Lillie.

Cook Strait.-(a) Porirua Harbour. Skull in British Museum. Described by Hector (1875). (b) Tory Channel. Two scapulas in Dominion Museum, Wellington. Described by Gray (1874). (c) Common, May to August. Motor-launches are engaged in whaling at Picton, catching 35 to 40 Humpbacks annually.

Kaikoura.-(a) Skull in Dominion Museum, Wellington. Described by Hector (1875). (b) A whaling-station is established here. Nine whales were brought in in each of the years 1918 and 1919.

Akaroa Harbour.-Female caught 6th May, 1875. Calf also killed. Described by von Haast (skeleton then in Canterbury Museum). Vertebræ: C. 7, D. 13, L. 10, Ca. 21=う1. Cervicals free. Sternum scarcely longer than broad. (Haast.) There is a skeleton in the British Museum, presumably this one.

Otago.-Right tympanic and periotic bone in British Museum. Described by Gray as the type of Megaptera novce zealandice.

\section{Physeter.}

Physeter Linné, 1758 , Syst. Nat. ed. 10, p. 76 ; type, P. macrocephalus Linné.

\section{Physeter macrocephalus.}

Physeter macrocephalus Linné, 1758, Syst. Nat. ed. 10, p. 76 (European seas); Hector, 1878, Trans. N.Z. Inst. vol. x. p. 337 ; Waite, 1909, Subant, Is. N.Z. p. 551. Catodon macrocephalus (L.), Hector, 1873, Trans. N.Z. Inst. vol. v. p. 157. Physeter catodon (L.), Lillie, 1915, 'Terra Nova' Exped., Zool. vol. i. p. 118. 
It has been the fashion recently to use the name Physeter catodon for this species, its only claim being priority of place on the page. On the other hand, its identity appears doubtful. Gray, Cope, and others applied it to the Arctic White Whale, whereas the identity of $P$. macrocephalus is clear, and the name has been in general use since its publication.

The Sperm Whale is found chiefly in tropical and warm temperate seas, though it occurs as far south as the south of New Zealand. It does not come close inshore like the Right Whale and Humpback, hence it is seldom cast ashore, although, strange to say, when this does happen, large schools are sometimes involved. It has been recorded off the Chatham and Campbell Islands. Lower jaws are preserved in the museums at Christchurch and Dunedin. There is also in the British Museum the lower jaw of a specimen taken between Cape Howe and New Zealand.

Kaipara Coast--(a) A school of 27 Sperm Whales-males, females, and young-stranded in 1895. (b) School of 25 stranded opposite Dargaville, March 1918. Length varied from 22 to $45 \mathrm{ft}$.

Cook Strait.-Head cast ashore at Waikanae (Hector, 1873).

South of New Zealand (Lat. S. $44^{\circ} 56^{\prime}$, Long. E. $172^{\circ} 53^{\prime}$ ).School of 12 seen 31st March, 1912 (Lillie).

\section{KOGIA.}

Kogia Gray: 1846, Zool. 'Erebus' \& 'Terror,' Mamm. p. 22 ; type, Physeter breviceps Blainville.

Kogia BReviceps. (Pl. II. fig. 3.)

Physeter breviceps Blainville, 1838, Ann. d'Anat. et Phys, vol.ii. p. 337 (Cape of Good Hope). Kogia breviceps Blainv., Hector, 1878, Trans. N.Z. Inst. vol. x. p. 337. Cogia breviceps Blainv,, Benham, 1901, Proc. Zool. Soc. 1901, vol. i. p. 278; id. 1901, l. c. vol. ii. p. 107 ; id. 1902 , l. c. vol. i. p. 54 ; id. 1902 , Trans. N.Z. Inst. vol. xxxiv. p. 155. Euphysetes pottsii von Haast, 1874 (June), Trans. N.Z. Inst. vol. vi. p. 97, pl. 15; id. 1874 (Oct.), Proc. Zool. Soc. 1874, p. 260.

Though a rare whale, the Pigmy Sperm Whale has been taken in all seas. Schulte in 1917 (Bull. Amer. Mus. Nat. Hist. vol. xxxvii. p. 361) listed 21 occurrences, three of which were from New Zealand. There are four skulls, without locality stated (but presumably from Lyall Bay and Petone), in the Dominion Museum, Wellington. Altogether at least 11 specimens have been cast ashore in New Zealand during the past 40 years.

Napier.-1892. Skull in Otago Museum.

Wanganui Beach.-(a) Skeleton and stuffed skin in the Wanganui Museum. Vertebræ: C. 7, D. 12, L. \& Ca. $26+=45+$. Cervicals fused. Capitulum of first rib articulates with centrum 
of last cervical. Dorsal fin small, falcate. (b) On 3rd February, 1909, I examined at Wanganui a specimen of Kogia breviceps which had been stranded at the Heads a few days before. Length, $180 \mathrm{~cm}$.; flipper, $27 \mathrm{~cm}$.; dorsal fin height, $9.5 \mathrm{~cm}$.; distance across flukes, $49 \mathrm{~cm}$. Black above, white below. The accompanying figure was made from a photograph taken at the Heads, where, it was reported, three individuals came ashore. (Pl. II. fig. 3.)

Cook Strait.-(a) Port Underwood. Mandible in Dominion Museum, Wellington. Length of ramus, $32 \mathrm{~cm}$; ; breadth at angle, $7 \cdot 5 \mathrm{~cm}$.; symphysis, $6 \mathrm{~cm}$.; width between rami at base, $28.5 \mathrm{~cm}$. Teeth: 14 on right side, 13 on left. (b) Lyall Bay. Cow and calf cast ashore, 1880. (c) Petone, Wellington Harbour. Cow and calf harpooned, 1884. (d) Lyall Bay, 1887. Skeleton in Dominion Museum, Wellington. Teeth 14.14. Sternum of three segments. Scapula with broad backwardly-directed acromion and shorter and narrowly-directed coracoid, the borders overlapping for the distal half or more. Ribs 12, of which 7 are two-headed. Vertebræ: C. 7, D. 12 , L. \& Ca. $20+=39+$.

Lyttelton Harbour.-Female stranded at Governor's Bay, 17th August, 1873, Skeleton and half cast in Canterbury Museum. Exterior and skeleton described by von Haast as the type of Euphysetes pottsii. Teeth 13 in each ramus of mandible. Vertebræ: C. 7 , D. 12 , L. 11 , Ca. $20=50$. Cervicals fused. Ribs 12, of which 6 are two-headed. Sternum of three segments, the first T-shaped. Phalanges: $1,10,7,5,4$.

Purakanui, Otago.-Stranded 23rd August, 1900. Skeleton in Cambridge University Zoological Museum. Descriptions by Benham-exterior and skeleton (1902); exterior and anatomy (Proc. Zool. Soc. 1901, p. 107); larynx (Proc. Zool. Soc. 1901, p. 278). Teeth 13 in each ramus of mandible, 1 on each side of upper jaw. Pelvis absent. Vertebræ: C. 7, D. 13, L. 9, Ca. 23 =52. Ribs 13 pairs, the very last small, 6 are two-headed. Sternum of 3 segments. Phalanges: R. 2, 10,7,6,3; L. 2, 9, 7, 6, 2. (Benham.)

\section{Berardius.}

Berardius Duvernoy, 1851, Ann. Sci. Nat. ser. 3, vol. xv. p. 51 ; type, $B$. arnuxii Duvernoy.

This genus comprises two species-one from New Zealand and the Argentine, and the other, B. bairdii, from the North Pacific.

\section{BerardiUs ARNuXiI.}

Berardius arnuxii Duvernoy, 1851, Ann. Sci. Nat. ser. 3, vol. xv. p. 51 (Akaroa, N.Z.); Gray, 1866, Cat. Seals \& Whales Brit. Mus. p. 348 ; von Haast, 1870 , Ann. Mag. Nat. Hist. ser. 4, vol. vi. p. 348 ; id. 1870 , Trans. N.Z. Inst. vol. ii. p. 190 ; Hector, 1870, Ann. Mag. Nat. Hist. ser. 4, vol. v. p. 222 ; id. 1873 , Trans. N.Z. Inst. vol. v. p. 169 ; id. 1878 , l. c. vol. x.p 338, 
pl. 16; Van Beneden \& Gervais, 1880, Ostéogr. Cét. pp. 377, 515, Atlas, pl. 21 bis, 23, 23 bis; True, 1910, Bull. U.S. Nat. Mus. 73, p. 68. Berardius arnouxi Duvernoy, Flower, 1872, Trans. Zool. Soc. vol. viii. p. 212, pls. 27-29; Beddard, 1900, Book of Whales, p. 228. "Ziphid Whale," Knox, 1871, Trans. N.Z. Inst. vol. iii. p. 125 ; Hector, 1871 , ib. p. 129, pls. $16,17$.

The Porpoise Whale has been recorded a number of times in New Zealand and once from La Plata (Marelli, Ann. Mus. Nac. Buenos Aires, vol. xxx. p. 411, 1920). The following eleven specimens appear to be all the authentic New Zealand records. Besides these, a whale measured by Knox (1871) at Porirua probably belonged to this species.

Chatham Island.-Skull in Otago Museum.

Coast near Wanganui.-Skeleton in Wanganui Museum. Skull-length, $115 \mathrm{~cm}$.; mandible, $104 \mathrm{~cm}$. Aveoli two in each ramus. Vertebræ: C. 7 , D. 10, L. \& Ca. $22+=39+$. Three cervicals fused. Ribs 10, of which 7 are two-headed, 8 th attached to centrum of 7 th dorsal, 9 th and 10 th attached to transverse processes of the corresponding vertebræ. Sternum : 1st and 2nd segments notched in front and behind, 3rd notched in front only; 4 th of two lateral pieces, broad in front, united for $6 \mathrm{~cm}$., free and obtusely pointed behind.

Cook Strait.-(a) Worser Bay, Wellington Harbour. Stranded January 1870. Skull and other bones in Dominion Museum, Wellington. Measurements of animal given by Knox. Skull described by Hector $(1871,1873)$. Length of skull, $120 \mathrm{~cm}$. Only one pair of alveoli present in mandible. (b) Entrance to Wellington Harbour. Captured 12th January, 1877. Skeleton in Dominion Museum, Wellington. Exterior and skeleton described by Hector (1878). Teeth two in each ramus of mandible near apex. Vertebræ: C. 7, D. 10, I. 13 , Ca. $17=47$. First three cervicals fused. Ribs 10, of which 8 are two-headed. Sternum of 5 segments. Phalanges: 1, 6, 5, 4, 3.

Saltwater Creek, north of Banks Peninsula.-Male, stranded 27th December, 1873. Skeleton in Canterbury Museum. Teeth 2.2. Vertebræ: C. 7, D. 10, L. 13 , Ca. $17=47$. Three cervicals fused. Ribs 10, of which 8 are two-headed. Sternum of four segments. Scapula with broad expanded acromion and narrow thick and but slightly broadening coracoid. Phalanges: 2, 5, $4,3,3$.

New Brighton Beach.- Stranded 16th December, 1868. Skeleton in Museum of Royal College of Surgeons, London. Exterior described by von Haast (1870). Skeleton described by Flower, Van Beneden \& Gervais, and Beddard. Vertebræ: C.7, D. 10, L. 12 , Ca. $19=48$. Three cervicals fused. Ribs 10 , of which 7 are two-headed. Phalanges: 2, 5, 4, 4, 3.

Akaroa.-(a) 1846. Skull in Paris Museum. Described by Duvernoy as the type of Berardius armuxii. Described and 
figured by Van Beneden and Gervais (p. 389, pl. 23). (b) Skeleton in British Museum.

Otago Peninsula.-1840. Mandible in Otago Museum. Teeth two in each ramus.

New Zealand (without locality stated).-(a) Skeleton in Paris Museum sent by von Haast. Figured by $\nabla$ an Beneden and Gervais (pls. 21 bis, 23 bis). (b) Skull in U.S. National Museum, Washington. Measurements given by True.

\section{MESOPLODON.}

Mesoplodon Gervais, 1850, Ann. Sci. Nat. ser. 3, vol. xiv. p. 16; type, Delphinus sowerbensis Blainville. Dioplodon Gervais, 1850, Comptes Rendus, vol. xxxi. p. 512 ; type, Delphinus densirostris Blainville. Oulodon von Haast, 1876, Proc. Zool. Soc. 1876, p. 457; type, Mesoplodon grayi von Haast. Dolichodon Gray, 1866, Cat. Seals \& Whales Brit. Mus. p. 353 ; type, Ziphius layardi Gray.

For an account of the species of this genus, see Forbes, Proc. Zool. Soc. 1893, p. 216, and Flower, 1872, Trans. Zool. Soc. vol. viii. p. 211.

Mesoplodon bowdorni. (Pl. 1II. figs. 1-3; Pl. IV. figs. 1-3.) Mesoplodon bowdoini Andrews, 1908, Bull. Amer. Mus. Nat. Hist. vol. xxiv. p. 203, pl. 13 (New Zealand).

This species is now known from two skeletons:-

(1) New Brighton Beach.-1904. Skeleton in American Museum of Natural History, New York. Described by Andrews.

Maxillary foramina approximately level with foramina in premaxillaries. Basirostral groove absent. Anterior margin of teeth posterior to hinder edge of mandibular symphysis. Vertebræ: C. 7 , D. 10 , L. 9, Ca. $20=46$. First three cervicals ankylosed. Chevrons 9. Ribs 10, of which 7 are two-headed. Sternum of four segments. Scapula with superior margin of acromion overlapping the coracoid border. Phalanges: 0, 4, 3, 3, 2. (Andrews.)

(2) New Zealand.--Skeleton in Dominion Museum, Wellington. This being the second specimen of the species known, a detailed description will be given :-

Skull: Length $72 \mathrm{~cm}$., of rostrum (from outside anteorbital notch) $43.5 \mathrm{~cm}$.; breadth of skull at squamosals $33 \mathrm{~cm}$., at orbits $31.8 \mathrm{~cm}$.; base of rostrum $12 \mathrm{~cm}$. Temporal fossæ $9.5 \times 6.5 \mathrm{~cm}$. Height from vertex to lower border of pterygoids $30 \cdot 2 \mathrm{~cm}$, of rostrum at anterior end of pterygoids $8 \cdot 2 \mathrm{~cm}$. (Pl. III. figs. 1-3.)

Maxillary foramina 3 on right side, 2 on left, about $1 \mathrm{~cm}$. in advance of the premaxillary foramina ( 1 on each side). Rostrum solid. Contour of upper edge of rostrum straight for two-thirds of its length, then slightly depressed ; of lower edge parallel with upper for the first third, then sloping upwards for the middle third, at $14 \mathrm{~cm}$. from apex its height being $5 \mathrm{~cm}$., then gradually narrowing to apex. A prominent ridge on each side of the 
expanded portion of the maxilla curving in anteriorly, and forming the lateral prominences at the base of the rostrum and dividing the anteorbital notches. Proximal ends of premaxillæ strongly everted and overhanging the nares; both directed obliquely backwards, the right $12.5 \mathrm{~cm}$., the left $7 \mathrm{~cm}$. long. Right nasal bone forming the vertex, the left smaller and lower. Mesorostral appearing between the premaxillæ throughout its length ; width at rostral base $2 \cdot 3 \mathrm{~cm}$., at $14 \mathrm{~cm}$. in advance $1 \mathrm{~cm}$., thence widening out towards the distal end. Its proximal end is a thin vertical ridge of bone. Foramen magnum $5 \times 4 \mathrm{~cm}$., occipital condyles $7 \times 4 \cdot 2 \mathrm{~cm}$. No basirostral groove. Temporal fossæ pyriform, above the level of the occipital condyles. On the lower surface of the skull the pterygoids diverge, showing the palatines as narrow divergent stripes on each side, about $10 \mathrm{~cm}$. long and $1 \mathrm{~cm}$. wide. Between the palatines the two edges of the maxillæ meet as a median ridge, the bones anteriorly diverging and exposing the vomer. The palatines appear again above the pterygoids, their anterior ends being level with the pterygoid fossæ. Pterygoids broken, but the exterior deeply concave and the basal portion parallel and meeting for a distance of $13 \mathrm{~cm}$.

Mandible: Length of ramus $63 \mathrm{~cm}$., of symphysis $15 \mathrm{~cm}$.; tip to anterior end of left tooth, $13.5 \mathrm{~cm}$; tooth-line along upper edge of ramus, $11 \mathrm{~cm}$.; width of ramus at posterior end, $12.5 \mathrm{~cm}$.; narrowest portion behind tooth $7 \mathrm{~cm}$., at anterior edge of tooth $6.5 \mathrm{~cm}$. The upper margin curves upwards and slightly outwards (but is not swollen) to form the walls of the alveolus, the internal wall being much higher than the external wall, which in the present specimen falls, but may be broken. (PI. IV. figs. 1 \& 2.)

Tooth : The left tooth only is preserved. Its anterior margin at its junction with the upper edge of the ramus is $15 \mathrm{~mm}$. in advance of the posterior end of the symphysis. Anteriorly the tooth is slightly concave, posteriorly strongly convex. The apex is directed slightly forwards. The base is formed of eight irregular fangs. Anterior margin, $13.8 \mathrm{~cm}$.; base, about 10.5 cm.; thickness, $2 \cdot 4 \mathrm{~cm}$.

Hyoid bones: Thyrohyals separate; length, $17 \mathrm{~cm}$. Other bones not preserved.

Vertebræ: C. 7 , D. 10, L. 9, Ca. 15=41. Atlas, axis, and third cervical fused by both centra and neural arches, 4th and 5 th fused oniy by the neural arch on the right side; 6 th and 7 th free. Atlas without diapophyses; two conical spines on crest. Diapophyses and parapophyses all separate. Seventh cervical with long diapophyses directed forwards, parapophyses reduced to knobs, above which are the articular facets for the tubercula of the first pair of ribs. Dorsals with centra concave above. Transverse processes of the anterior seven opposite the neural arches and bearing articular facets for the tubercula of the first seven ribs. The first six dorsals bear tubercles on the posterior edges of the centra for the articulation of the capitula of the $2 \mathrm{nd}$ to 7 th ribs. The 8 th, 9 th, and 10 th dorsals bear short transverse 
processes ending in articular facets for the heads of the last three ribs. On the 8 th and following vertebræ the transverse processes and metapophyses are widely separated, the former being opposite the centra. Lumbars with strong inferior median carina. Neural spines truncated and expanded at their distal ends. Metapophyses lamellar, projecting forward and upward. Anterior 11 caudals showing facets for chevron bones. The last four are depressed oblong bones with no processes, but there appear to be some missing between the two series. Transverse processes reduced to ridges on the 8th caudal, neural spine rudimentary on the 11th (the 12th and other caudals presumably missing).

Ribs, 10 pairs. The first seven are two-headed, articulating by both capitula and tubercula. The first articulates with the centrum of the 7 th cervical and the transverse process of the first dorsal, the 7 th articulates with the centrum of the 6 th and the transverse process of the 7 th dorsal. The 8 th, 9 th, and 10 th are single-headed and articulate with the transverse processes of the 6 th to 10 th vertebræ. The first two ribs broad and flat, with the proximal ends strongly curved; the remainder with the proximal ends below the articular tubercles roughly triangular or quadrangular in section, the distal ends being flattened.

The greatest length of each rib on the right side in a straight line is as follows:-1st, $30.5 \mathrm{~cm} . ; 2 \mathrm{nd}, 46 \cdot 8 \mathrm{~cm}$.; $3 \mathrm{rd}, 54 \cdot 7 \mathrm{~cm}$.; 4 th, $59.0 \mathrm{~cm}$; 5 th, $60.3 \mathrm{~cm}$; 6th, $60.4 \mathrm{~cm}$; 7 th, $60.0 \mathrm{~cm}$; 8 th, $55 \cdot 2 \mathrm{~cm}$; 9 th, $50 \cdot 5 \mathrm{~cm}$.; 10 th, $42.5 \mathrm{~cm}$.

Sternum: The sternum consists of four segments. Three fenestræ are formed at the junctions by notches in the middle of the anterior and posterior margins of the segments. There is a fourth fenestra in the centre of the posterior segment. On each side are five facets for the articulation of the costal ribs-one on the anterior segment, one on the posterior, and one at each of the junctions.

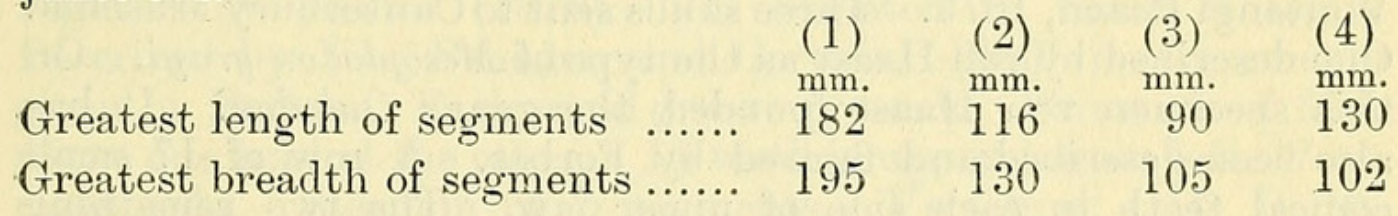

Scapula: Breadth, $30 \cdot 4 \mathrm{~cm}$., length (median), $20 \mathrm{~cm}$. Median length of acromion and coracoid, each about $9 \mathrm{~cm}$. Acromion broad, lamellar projecting upward. Coracoid slender, expanded distally. The superior margin of the acromion is clear of the coracoid border. (Pl. IV. fig. 3.)

Comparison with type of $M$. bowdoini:-The present specimen differs from the type of $M$. bowdoini from New Brighton in no important respect. In the general proportions of the skull and mandible they appear to be within the range of individual variation, and agree in those characters separating $M$. bowdoini as a species: these are the absence of a basirostral groove, short symphysis of mandible, position and size of tooth, relative positions of palatines and pterygoids, overhanging maxillary crest, and 
form of the rostrum. On the other hand, the anterior edge of the tooth in the New Brighton specimen is $15 \mathrm{~mm}$. behind the posterior margin of the mandibular symphysis; in the Dominion Museum specimen it is about $14 \mathrm{~mm}$. in advance of it. According to my description, the 8 th to 10 th dorsal vertebræ have the corresponding ribs articulated to their transverse processes. Andrews states that the 8 th rib of $M$. bowdoini is articulated to a facet on the posterior margin of the centrum of the 7 th dorsal. The superior margin of the acromion in the type of $M$. bowdoini overlaps the coracoid border, whereas it is clear of it in the present specimen.

\section{MESOPLODON GRAYI.}

Mesoplodon grayi von Haast, Proc. Zool. Soc. 1876, p. 7 (Chatham Island); Flower, 1878, Trans. Zool. Soc. vol. x. p. 417, pls. 71-73 ; Forbes, 1893, Proc. Zool. Soc. 1893, p. 216, pls. 12-15. Mesoplodon hectori (not Gray) Hector, 1874, Trans. N.Z. Inst. vol. vi. p. 86, pl. $15 \mathrm{~A}$; id. 1876, l. c. vol. x. p. 339 , pl. 17. Berardius hectori (not Gray) Hector, 1875, 1. c. vol. vii. p. 262. Oulodon grayi von Haast, 1876. Proc. Zool. Soc. 1876, p. 457 ; id. 1877, Trans. N.Z. Inst. vol. ix. p. 450, pl. 26 ; Van Beneden \& Gervais, 1880, Ostéogr. Cét. p. 516, pl. 62. Mesoplodon haasti Flower, 1878, Trans. Zool. Soc. vol. x. p. 419, pls. 71, 72. Mesoplodon australis Flower, 1878, l. c. p. 419, pls. 71-73; Lillie, 1915, 'Terra Nova' Exped., Zool. vol. i. p. 119. Mesoplodon knoxi part (skull B) Hector, 1873, Trans. N.Z. Inst. vol. v. p. 167.

The New Zealand Scamperdown Whale appears to be fairly cornmon in the New Zealand region. Elsewhere it has been recorded only from Patagonia.

Chatham Islands.-(a) About 25 individuals stranded on Waitangi Beach, 1875. Three skulls sent to Canterbury Museum. One described by von Haast as the type of Mesoplodon grayi. On this specimen von Haast founded the genus Oulodon. It has also been described and figured by Forbes. A row of 17 small conical teeth in each side of upper jaw. The two remaining skulls in the Otago Museum. One has 17, the other 19 teeth in each side of the upper jaw. (b) Skeleton in U.S. National Museum, Washington. Vertebræ: C. 7, D. 11, L. 10, Ca. $20=48$. Two cervicals fused. Chevrons 9. Ribs 11, of which 7 are twoheaded; the last rib rudimentary, about $70 \mathrm{~mm}$. long. (c) Skull and three rostra in British Museum. Described by Forbes. (d) Skeleton in Bishop Museum, Honolulu. Figured in Occ. Papers Bishop Mus. vol. i. no. 5, figs. 4-8, 1902. Ribs 9. Premaxillary behind maxillary foramina.

North Cape.-Skeleton found in Great Exhibition Bay, August 1911. Skull and scapula in British Museum. Described by Lillie. Basirostral groove present. Foramina of fifth nerve one behind the other. Height of teeth, 3 in.; length, $2 \frac{1}{2}$ in. (Lillie.) 
East Coast, North Island.-Male stranded, December 1875. Rostrum in Museum of Royal College of Surgeons, London. Described by Flower as the type of M. haasti. Measurements given by Forbes. Basirostral groove present. Foramina of fifth nerve one behind the other.

Cook Strait.-(a) Lyall Bay. Cast ashore, January 1875. Skeleton in British Museum. Exterior and skeleton described by Hector (1875). Skeleton described by Flower as the type of M. australis. Skull measurements given by Forbes. Basirostral groove deep. Vertebræ: C. 7, D. 9, L. 11, Ca. $20=47$. Two cervicals united. Ribs 9, of which 7 are two-headed. (Flower.) (b) Wellington. Skeleton in American Museum of Natural History, New York.

Kaikoura.-Mandible described and figured by Hector (1874).

Saltwater Creek, 30 miles north of Banks Peninsula.-Male stranded 15th December, 1876. Two males and a female stranded 29th December, 1876. Skeleton of one in Canterbury Museum. Skull measurements given by Forbes. Basirostral groove present. Vertebræ: C. 7, D. 10, L. 11, Ca. 19=47. Two cervicals fused. The 8 th and 9 th caudals are joined by a bony growth. Ribs 10 , of which 7 are two-headed. Sternum of 4 segments; 1st large, bifid in front, 2nd and 3rd notched in front and behind, 4th composed of three fused pieces, pointed posteriorly and with a central foramina. Phalanges: $1,6,6,4,3$. Skeleton of another in Museum of Royal College of Surgeons, London. Described by Flower and Forbes. Basirostral groove shallow. Vertebræ: C. 7 , D. 10 , L. 11 , Ca. $20=48$. Two cervicals fused. Ribs 10, of which 7 are two-headed. (Flower.)

Kaicupoi.-Skull in Canterbury Museum. Described by Hector (1873) and Forbes.

New Zealand (locality not strited).-(a) Skull in Otago Museum. Figured by Hector (1878). (b) Skeleton in Paris Museum. Described by Van Beneden and Gervais. Skull measurements given by Forbes. Basirostral groove present. Foramina of fifth nerve one behind the other. 18 teeth in upper jaw on left, 17 on right side. Sternum of 5 segments. Vertebræ: C. 7, D. 10, C. 11 , Ca. $19=47$. Two cervicals fused. Chevrons 10. Ribs 10, of which 7 are two-headed. Phalanges: $0,6,5,4,2$. (c) Skeleton in Lominion Museum, Wellington. Rostrum narrow, deeper than wide at base. Basirostral groove deep. Foramina of fifth nerve one behind the other. Maxillary large, directed forwards; premaxillary small, behind and directed upwards. Length of skull $75 \mathrm{~cm}$., of rostrum $45 \mathrm{~cm}$; width at squamosals, $28 \mathrm{~cm}$.; base of rostrum, $5 \mathrm{~cm}$. Mandible length, $67 \mathrm{~cm}$.; symphysis, $21.5 \mathrm{~cm}$. This skull approaches closely the type of $M$. austratis. Ribs 10, of which 7 are two-headed. Sternum of 4 segments; the first two free and notched in front and behind, the lasi two completely fused, the line of junction being denoted by a foramen. 


\section{Mesoplodon layardi.}

Ziphius layardi Gray, 1865, Proc. Zool. Soc. 1885, p. 358 (Cape of Good Hope). Dolichodon layardi Gray, Hector, 1873, Trans. N.Z. Inst. vol. v. p. 166, pl.3. Mesoplodon layardi Gray, Hector, 1873, Ann. Mag. Nat. Hist. ser. 4, vol. xi. p. 106 ; id. 1878, Trans. N.Z. Inst. vol. x. p. 341 ; Flower, 1878, Trans. Zool. Soc. vol. x. p. 416; Turner, 1880, 'Challenger' Rep., Zool. vol. i. pt. 4, p. 2, pls. 1-3; Waite, 1912, Rec. Cant. Mus. vol. i. p. 326, pl. 62 ; id. 1912, Guide Whales \& Dolph. N.Z. p. 16, pl. 4. Mesoplodon floweri von Haast, 1876, Proc. Zool. Soc. 1876, p. 478; id. 1877, Trans. N.Z. Inst. vol. ix. p. 442, pls. 25, 26. Dolichodon traversii Gray, 1874, Trans. N.Z. Inst. vol. vi. p. 95.

The Strap-toothed Whale has been recorded from South Africa, Australia, and New Zealand.

Turner.

Chatham Island.- Mandible described by Hector (1873) and

Great Barrier Island.-Skull in Canterbury Museum. Teeth meeting over the upper jaw.

Napier.-Teeth in Otago Museum.

Marlborough.-Skull in Dominion Museum, Wellington; acquired 1879. Length of teeth following curvature, $34 \mathrm{~cm}$.; greatest width, $60 \mathrm{~mm}$. Denticle $7 \mathrm{~mm}$. high, $10 \mathrm{~mm}$. along base-line.

Saltwater Creek, north of Banks Peninsula.-Stranded 16th March, 1874. Skeleton in Canterbury Museum. Described by von Haast as the type of M. floweri. Vertebræ: C. 7, D. 10, L. 10 , Ca. $19=46$. Three cervicals fused. Ribs 10, of which 7 are two-headed. Sternum of 4 segments. Scapula with broad acromion and narrow coracoid. Phalanges : 2, 5, 5, 4, 3 .

Lyttelton Harbour.-Specimen stranded at Allendale, 22nd March, 1912. Half cast in Canterbury Museum. Exterior described by Waite.

Locality not stated.-(a) Skull in Dominion Museum, Wellington. Length, 94.5 cm.; breadth, $41 \mathrm{~cm}$.; mandible length, $80 \mathrm{~cm}$.; symphysis, $22 \mathrm{~cm}$. Basirostral groove deep. (Teeth missing.) (b) Skelton in Dominion Museum. Basirostral groove shallow. Length of skull, $61 \mathrm{~cm}$.; of mandible, $52 \mathrm{~cm}$. Vertebræ: C. 7, D. 9, L. 12, Ca. 16=44. Two cervicals fused. Ribs 9, of which 7 are two-headed. Sternum of 3 segments. I have identified this specimen from cranial characters. It is from a young animal, and the teeth are small and triangular. They only differ from those of $M$. grayi in being strongly incurved.

\section{Paikea, gen. n.}

I propose this name for those species of Ziphioid Whales with the cranial characters of Mesoplodon and two terminal teeth in the lower jaw. Type, Berardius hectori Gray. The only other species that can be referred to this genus is Mesoplodon mirum. 
True, from the North Atlantic. The essential character is the position of the teeth. Other characters which these species have in common are the broad and deep rostrum and the long mandibular symphysis; also, the dorsal fin is placed far back and the teeth completely covered by the gums. In Mesoplodon, as it is now proposed to restrict it, the teeth are always placed near the posterior end of the symphysis so that the two species comprising Paikea apparently form a natural group in which the teeth, as pointed out by Dr. Harmer (Report Cetacea on British Coasts 1918 , p. 21, 1919), possibly correspond with the anterior pair of Berardius.

The reduction of the teeth from four to two in the Ziphioid Whales is interesting. Birardius is perhaps the most primitive of the recent genera and has usually four teeth, but in a skull in the Dominion Museum, Wellington, only the anterior pair is present. In Ziphius and Hyperoodon it is the anterior pair that is retained, but in Mesoplodon the posterior pair only is present. Paikea differs from Mesoplodon in possessing only the anterior pair of mandibular teeth.

\section{Paikea hectori.}

Berardius hectori Gray, 1871, Ann. Mag. Nat. Hist. ser. 4, vol. viii. p. 117 ; Hector, 1873, Ann. Mag. Nat. Hist. ser. 4, vol. xi. p. 106. Berardius arnuxii (not Duvernoy) Hector, 1870, Trans. N.Z. Inst. vol. ii. p. 27. "Ziphid Whale," Knox \& Hector, 1871, l. c. vol. iii. p. 125 , pls. 14, 15. Mesoplodon knoxi Hector, 1873 , l. c. vol. v. p. 167. Mesoplodon hectori Gray, Flower, 1878, Trans. Zool. Soc. vol. x. p. 416, pls. 71, 72 ; Forbes, 1893, Proc. Zool. Soc. 1893 , p. 227.

Known only from the following specimen :-

Titahi Bay, Cook Strait.-Cast ashore January 1866. Skull in British Museum. All the references quoted refer to this specimen. Basirostral groove absent. Foramina of fifth nerve level.

\section{ZipHIUs.}

Ziphius G. Cuvier, 1823, Ossem. Foss. vol. v. p. 350, pl. ; type, Z. cavirostris Cuv. Hypodon Haldeman, 1841, Proc. Acad. Nat. Sci. Philad. vol. i. p. 127 ; type, Delphinus desmaresti Risso $(=H$. cavirostris).

If Ziphius and Xiphias be considered variations of the same word, then Ziphius Cuvier, 1823, is preoccupied by Xiphias Iinné, 1758, a genus of fishes, and the next valid name to be used for the genus of whales is Hypodon Haldeman, 1841. Professor David Starr Jordan points out to me that Ziphius seems to have been purposely so written by Ouvier perhaps to make it clearly different from Xiphias, which name was also used by the same author. 


\section{ZIPHIUS CAVIROSTRIS.}

Ziphius cavirostris G. Cuvier, 1823, Ossem. Foss. vol. v. p. 350 (Mediterranean coast of France) ; Flower, Proc. Zool. Soc. 1876, p. 477 ; Hector, 1878, Trans. N.Z. Inst. vol. x. p. 342 ; Turner, 1880, 'Challenger' Rep., Zool. vol. i. pt. 4, p. 27, pl. 2. Epiodon chathamiensis Hector, 1873, Ann. Mag. Nat. Hist. ser. 4, vol. xi. p. 105 ; id. 1873, Trans. N.Z. Inst. vol. v. 164, pls. 4, 5. Epiodon novee zealandice von Haast, 1877, Trans. N.Z. Inst. vol. ix. p. 430, pls. 24, 26. Ziphius novce zealandice von Haast, 1876, Proc. Zool. Soc. 1876 , p. 466 ; id. 1880 , Proc. Zool. Soc. 1880 , p. 232 ; id. 1880, Trans. N.Z. Inst. vol. xii. p. 241, pl. 8. Ziphius sp., Scott \& Parker, 1889, Trans. Zool. Soc. vol. xii. p. 241, pls. 48-50; Beddard, 1900, Book of Whales, p. 235, pl. 12; Benham, 1901, Proc. Zool. Soc. 1901, vol. i. p. 294. Hyperoodon planifrons (not Flower) Waite, 1913, Rec. Cant. Mus. vol. ii. p. 23, pls. 8, 9.

The Goose-beaked Whale has been recorded from all seas.

Chatham Island.--(a) Skull in Dominion Museum, Wellington. Described by Hector as the type of Epiodon chathamiensis. (b) Teeth in British Museum. One figured by Hector, Trans. N.Z. Inst. vol. v. pl. v. figs. $2 a, 2 b$.

East Cape, North Island.-Teeth and extremity of mandible in Canterbury Museum. Described and figured by Waite, who referred it with doubt to Hyderoodon planifrons, but his figure almost matches the anterior end of the mandible of the Petone specimen.

Cook Sirait.-(a) Near Wellington. Skull described by Turner. (b) Petone Beach, Wellington Harbour. Stranded October 1919. Skeleton in possession of $\mathrm{Mr}$. H. H. Travers, Wellington. Vertebræ: C. 7 , D. 9, L. 11 , Ca. $19=46$. First four cervicals fused, 5th and 6 th separately fused by neural arch on left side. Last spinous process and neural canal on the 11 th caudal. Ribs 9, of which 6 are two-headed. Sternum of 5 segments, the first 4 are notched in front and behind, the last of two separate lateral pieces. Scapula with long acromion and coracoid.

Kaiapoi Beach.-Female, stranded 15th May, 1879. Skeleton in British Museum. Teeth described by von Haast (1880).

New Brighton Beach.- Stranded 17th November, 1878. Exterior and teeth described by von Haast (1880).

Lyttelton Harbour.--Stranded at Port Cooper, July 1872. Skeleton in Canterbury Museum. Described by von Haast as the type of Ziphius novee zealandice. Vertebræ: C. 7, D. 9, L. 11, Ca. $19=46$. Four cervicals fused. Ribs 9, of which 7 are twoheaded. Sternum of 5 segments, each notched anteriorly and posteriorly. Scapula with long, narrow acromion and coracoid. Phalanges : 2, 5, 5, 4, 3 .

Akaroa Harbour.-Female, stranded July 1873. Skull described by von Haast (1877).

Warrington, Otago.-Came ashore alive, 6th November, 1884. Skeleton in Otago Museum. External characters, skeleton, and 
anatomy described by Scott and Parker; larynx described by Benham. Two sharp-pointed teeth at apex of mandible. Vertebræ: C. 7 , D. 10, L. 9. Ca. $20=46$. Four cervicals fused. Ribs 10, of which 7 are two-headed. Sternum of 5 segments, each notched in front and behind. Pelvic bones about $9 \mathrm{~cm}$. long. Phalanges: 1, 5, 5, 5, 2 .

Locality not stated.-Skull of young in British Museum.

\section{Orcinus.}

Orcinus Fitzinger, 1860, Wiss.-populäre Naturg. Säug. vol. vi. p. 204 ; type, O. orca (= Delphinus orca Linné). (Orca Gray, 1846, is preoccupied by Orca Wagler, 1830, a genus of Physeteridæ.)

\section{ORCINUS ORCA.}

Delphinus orca Linné, 1758, Syst. Nat. ed. 10, p. 77 (European seas). Orca gladiator Gray, 1846, Zool. 'Erebus' \& 'Terror,' p. 33 ; Hector, 1885, Trans. N.Z. Inst. vol. xviị. p. 208 . Orca pacifica Gray, Hector, 1875, l. c. vol. vii. p. 260.

The Killer Whale is found in all seas. Lillie has recorded it as far south as McMurdo Sound, and states that it is the commonest cetacean in the Ross Sea. It is occasionally seen off the New Zealand coast, especially about Cook Strait. Besides the following definite records, there is a skull of unknown locality in the Auckland Museum.

Chatham Island.-Skull in Canterbury Museum. Teeth $\frac{1}{13}$.

Coast south of Wanganui.-Skeleton in Dominion Museum, Wellington. Vertebræ: C. 7, D. 11, L. 10, Ca. $24=52$. Four cervicals fused; 5th and 6th separately fused by neural arches only. Teeth $\frac{11}{12}$. Ribs 11, of which 6 are two-headed. Sternum of one piece with five articular facets on each side.

Otago Heads.-Skull in Otago Museum. Described by Hector (1875). Teeth $\frac{12}{12}$.

\section{Pseudorca.}

Pseudorca Reinhardt, 1862, Overs. K. Danske Vidensk. Selsk. Forhandl. p. 151 ; type, P. crassidens (=Phoccena crassidens Owen).

\section{PSEUdORCA CRASSIDENS.}

Pseudorca crassidens Owen, 1846, Brit. Foss. Mamm. p. 516 (North Sea). Pseudorca meridionalis Flower, Hector, 1873, Trans. N.Z. Inst. vol. v. p. 163.

The range of this species, which may be called the Tasmanian Blackfish, extends from the North Sea to the Chatham Islands. It is met with in large schools in New Zealand and Tasmanian waters. 
Chatham Island.-In March 1906 a school of several hundreds was stranded on Long Beach, Petre Bay. These were referred to by Waite (Subant. Is. N.Z. p. 551, under Globiocephalus melas), who visited the locality in February 1907. In December 1909 the remains of many of them were still to be seen, and I was able to identify the species as Pseudorca crassidens. Teeth in upper jaw 8 on each side.

Lyall Bay.-Cranium in Dominion Museum, Wellington. Described by Hector. This was at one time referred by Hector to Beluga (Ann. Mag. Nat. Hist. ser. 4, vol. ix. p. 438, 1872).

\section{Globicephala.}

Globicephala Lesson, 1828, Hist. Nat. Mamm. et Ois. vol. i. p. 141 ; type, Delphinus deductor Scoresby (=D. melas Traill).

\section{Globicephala melena.}

Delphinus melas Traill, 1809, Nicholson's Journ. vol. xxii. p. 21 (North Atlantic). Globiocephalus macrorhynchus Gray, Hector, 1870, Trans, N:Z. Inst. vol, ii. p. 28 ; id. 1873 , l. c. vol. v. p. 164 ; id. 1875 , l. c. vol. vii. p. 261 , pls. $16,16 \mathrm{~A}$; id. 1877 , l. c. vol. ix. p. 481 , pls. $13,13 \mathrm{~A}$; id. 1870 , Ann. Mag. Nat. Hist. ser. 4, vol. v. p. 222. Globicephalus melas Traill, Hector, 1885, Trans. N.Z. Inst. vol. xvii. p. 209 ; Waite, 1909, Subant. Is. N.Z. p. 551.

The Blackfish is found in all tropical and temperate seas. Like its relative the Tasmanian Blackfish, it goes about in schools. It is occasionally reported stranded in considerable numbers, but as the term "blackfish" is popularly applied to several species, the specific identity is not always certain. Skeletons and skulls are common in New Zealand museums.

Chatham Islands.-Skull in Dominion Museum, Wellington (according to Hector, Ann. Mag. Nat. Hist. ser. 4, vol. xi. p. 105, $1873)$.

Cook Strait.-(a) Two skulls and other bones in the Dominion Museum. Described by Hector $(1870$, p. $28 ; 1873)$. One of the skulls is very massive, measuring $67 \cdot 5 \mathrm{~cm}$. in length and $47.5 \mathrm{~cm}$. in breadth. Rostrum : length, $34 \mathrm{~cm}$.; breadth at base, $26.5 \mathrm{~cm}$. Pterygoids approximating to within 3 or $4 \mathrm{~mm}$. Teeth $\frac{9}{8}$. Intermaxillaries broad, expanding a little in front, approaching to within $2 \mathrm{~cm}$. of the edge of the maxillaries, upper surface rugose anteriorly. Six cervical vertebræ fused. (b) Lyall Bay. School ran ashore, January 1876. Ten skeletons were secured. One now mounted in Dominion Museum. Exterior of animal and skeleton described by Hector (1877). Teeth $\frac{10}{9}$. Vertebræ: C. 7 , D. 11 , L. 13 , Ca. $29=60$. Six cervicals fused. Ribs 11 , of which 7 are two-headed. Phalanges: 4, 13, 10,3, 1. Two skeletons in the British Museum are perhaps from this school. (c) Skeleton in Otago Museum. Teeth $\frac{?}{10}$. Vertebræ: C. 7, D. 11, L. 12, Ca. $26=56$. Four cervicals fused. Ribs 11, of which 6 are 
two-headed. Sternum of 3 segments, the first two perforated, the last divided longitudinally.

Otago.-Skeleton in Canterbury Museum. Pterygoids separated along the middle line of about $1 \mathrm{~cm}$. Teeth $\frac{10}{10}$. Vertebræ: C. 7 , D. 11, L. 14, Ca. $24=56$. Six cervicals fused. Pelvic bones curved, rod-like, about $15 \mathrm{~cm}$. long. Ribs 11, of which 6 are two-headed. Sternum of 3 segments, the anterior one notched in front, perforated in the centre, and with the sides projecting outwards and backwards. Scapula with broad L-shaped acromion, coracoid with distal end expanded.

Stewart Island.-(a) Skull in Otago Museum. (b) Captured January 1874. Skeleton in British Museum, exterior described by Hector (1875).

Campbell Island.-(Filhol, Mission d'Ile Campbell, Zool. p. 34, 1885, G. macrorhynchus).

Locality not stated.-(a) Skull in Auckland Museum. Figured by Hector (1875, pl. 16). (b) Skeleton in Dominion Museum. Teeth $\frac{8}{8}$. Vertebræ: C. 7 , D. 11, L. 13 , Ca. 25=56. Five cervicals fused. Ribs 11, of which 6 are two-headed. Sternum of 3 segments.

\section{Grampus.}

Grampus (\$ Delphinus) Gray, 1828, Spicilegia Zoologica, vol. i. p. 2 ; type, Delphinus griseus Cuvier.

\section{Grampus Griseus.}

Delphinus griseus Cuvier, 1812, Ann. Mus. vol. xix. p. 14 (Brest, France). Grampus richardsoni Gray, Hector, 1873, Trans. N.Z. Inst. vol. v. p. 163. Grampus griseus Cuv., Waite, 1912 , Rec. Cant. Mus. vol. i. p. 328, pl. 63 ; id. 1912, Guide Whales \& Dolph. N.Z. p. 19, pl. 5 .

Risso's Dolphin has been recorded in such widely sundered regions as the North Sea and the coast of New Zealand. It is a rare species wherever found. Only twice has it been recorded from our seas.

(1) Manawatu Beach.-Mandible in Dominion Museum, Wellington. Described by Hector. Length of ramus $44.5 \mathrm{~cm}$., of symphysis $6 \mathrm{~cm}$. Teeth 3 on each side opposite the symphysis, blunt, conical, the posterior one $8 \mathrm{~mm}$. in diameter and projecting $8 \mathrm{~mm}$. above the dried gum.

(2) Pelorus Sound.-Figured by Waite. It is strange that the famous cetacean known as "Pelorus Jack" should not have. been mentioned in scientific literature until Waite in a short note confirmed the identification of the Rev. D. C. Bates, and published a photograph showing the contour of the dorsal fin and flukes. It has an extensive literature in newspapers and magazines. A special booklet by J. Cowan has been devoted to it, while an article on "Pelorus Jack-Tuni-Rangi," by W. T. Downes, appears in the Journal of the Polynesian Society, vol. xxiii. p. 176,1914 . Both these give the Maori legend.

Proc. Zool. Soc.-1922, No. XL. 
"Pelorus Jack" has been described as "bluish-white tinged with yellow and purple, and with irregular brown-edged scratchlike lines in all directions. His flippers are blackish and mottled with grey" (Cowan). Length about $14 \mathrm{ft}$. Dorsal fin high and falcate. This famous cetacean for many years frequented the waters outside the entrance to Pelorus Sound, and was in the habit of meeting steamers on the route between Nelson and Wellington. It accompanied the vessels for some miles, and played from side to side of the bows, keeping just in front and frequently leaping out of the water. It was protected by an Order in Council. "Pelorus Jack" has not been seen since 1912.

\section{Cephalorhynchus.}

Cephalorhynchus (§ Delphinus) Gray, 1846, Zool. 'Erebus' \& 'Terror,' Mamm. p. 36 ; type, D. heavisidii Gray.

\section{Cephalorhynchus hectori. (Pl. II. figs. 1 \& 2.)}

Electra hectori Van Beneden, 1881, Bull. Roy. Acad. Belg. ser. 3, vol. i. p. 887, pl. 2. Lagenorhynchus clangulus (not Gray) Hector, 1870, Trans. N.Z. Inst. vol. ii. p. 27 ; id. 1872, Ann. Mag. Nat. Hist. ser. 4, vol. ix. p. 436, fig. Electra clangula (not Gray) Hector, 1873, Trans. N.Z. Inst. vol. v. p. 160, pl. 12 ; id. 1877, l. c. vol. ix. p. 350, pl. 11. Cephalorhynchus hectori Ben., Hector, 1885, Trans. N.Z. Inst. vol. xvii. p. 209 ; True, 1889, Bull. U.S. Nat. Mus. xxxvi. pp. 112, 177, pl. 32. Cephalorhynchus albifrons True, 1899, 1. c. pp. 111, 177, pl. 32.

Confined to New Zealand seas. It is the Common White-nosed Porpoise, never seen far from the coast.

North Coast.- Specimen captured. Skeleton in Paris Museum. Described by Van Beneden as the type of Electra hectori. Teeth 30. Vertebræ: C. 7, D. 14 , L. 15, Ca. $27=63$. Two cervicals fused. Ribs 14.

Bay of Islands.-Skull in Dominion Museum. Teeth 30. Length of skull $30.5 \mathrm{~cm}$., of rostrum $14.5 \mathrm{~cm}$.; width of rostrum at base, $7 \cdot 5 \mathrm{~cm}$.

WanganuiCoast.-(a) Skeleton in Wanganui Museum. Sternum of two segments; four pairs of ribs articulate with the anterior and one pair with the posterior segment, which is perforated. Two cervicals fused. (b) Stuffed skin in Wanganui Museum. Specimen stranded alive, Castlecliff Beach, May 1921. Mr. G. Shepherd, Curator of the Wanganui Museum, has kindly supplied me with a description which enables me to give the following particulars. Forehead grey. Snout and a margin round the grey of the forehead, black. Dorsal surface slaty black, shading into slaty grey on the sides and then into black bordering the white under surface. Tip of lower jaw, flippers, dorsal fin, and tail black. A white spot in the axil of each flipper. Under surface white, interrupted by an isthmus of black connecting the two flippers. The white extends backwards to midway between 
the vent and the flukes, dividing into three equally long pointed (Pl. II. figs. 1 \& 2) bands, one central and one extending obliquely along each flank. An elongated dusky patch surrounds the vent. Total length of specimen $1.90 \mathrm{~m}$. An interesting point to observe is that, according to Mr. Shepherd, the forehead is grey and not white. This intermediate colour probably accounts for the varying deseriptions given to this animal, resulting in it having been listed under two names.

Cook Strait.-(a) Outside Wellington Harbour. Described by Hector (1870). Vertebræ: C. 7, D. 14, L. \& Ca. 48=69. (b) Off Cape Campbell. Two shot from a large school. Exterior described by Hector $(1872,1873)$. (c) Wellington Harbour. Skull in Dominion Museum. Teeth $\frac{31}{32}$. Length of skull $31 \cdot 2 \mathrm{~cm}$., of rostrum $16 \mathrm{~cm}$.; width of skull at squamosals $16 \mathrm{~cm}$., of rostrum at base $8 \mathrm{~cm}$. (d) Half model in Otago Museum. There is also a skeleton, perhaps of this specimen, but locality not given.

Canterbury.-(a) Skeleton from Banks Peninsula in Canterbury Museum. Vertebræ: C. 7, D. 13, L. 15, Ca. 29=64. Two cervicals fused. Ribs 13 , of which 4 are two-headed, last rib less than half the length of the 12th. Sternum of one piece. (b) Skull in U.S. National Museum, Washington.

\section{LAGENORHYNCHUS.}

Lagenorhynchus Gray, 1846, Zool. 'Erebus' \& 'Terror,' Mamm. p. 30 ; type, Delphinus acutus Gray.

\section{LAGENORHYNCHUS OBSCURUS.}

Delphinus obscuirus Gray, 1828, Spic. Zool. p. 2 (Cape of Good Hope). Clymenic obscura Gray, Hector, 1873, Trans. N.Z. Inst. vol. v. p. 160 , pl. 1 ; id. 1877 , 1. c. vol. ix. pl. 11 ; id. 1885 , 1. c. vol. xvii. p. 211 ; Hutton, 1877, l. c. vol. ix. p. 349.

The Dusky Dolphin is common round the coast. It is apparently widely distributed, being recorded from the Cape seas and in the Southern Ocean as far south as $58^{\circ} \mathrm{S}$. lat. (Lillie.)

Wanganui Coast.-(a) Skull in Dominion Museum, Wellington. Described by Hector (1873). Teeth $\frac{34}{?}$. Length of skull, $35.5 \mathrm{~cm}$; ; breadth at squamosals, $16.7 \mathrm{~cm}$.; rostrum length, $19.3 \mathrm{~cm}$.; breadth at base, $8 \cdot 5 \mathrm{~cm}$. (b) Two specimens in Wanganui Museum.

Cook Strait.-Skeleton in Dominion Museum. Teeth $\frac{30}{31}$. Vertebræ: C. 7 , D. 13, L. 19, Ca. $32=71$. Two cervicals fused. Ribs 13, of which 6 are two-headed. Phalanges: 2, 9, 6, 2, 1. Sternum of 3 segments.

Banks Peninsula.-(a) Lyttelton Harbour. Skull in Canterbury Museum. (b) Akaroa. Cast in Canterbury Museum.

There are two other skeletons of unknown locality in the Dominion Museum. 


\section{LISSODELPHIS.}

Lissodelphis Gloger, 1841, Hand- u. Hilfsb. Naturg. vol. i. pp. xxxiv, 169; type, Delphinus peronii Lacépède. (Tursio Wagler, 1830, is preoccupied by Tursio Fleming, 1822, a genus of Physeteridæ.)

\section{LISSODELPHIS PERONII.}

Delphinus peronii Lacépède, 1804, Hist. Nat. Cét. p. 316 (south of Tasmania). Tursio peronii Lacép., Lillie, 1915, 'Terra Nova" Exped., Zool. vol. i. p. 121.

This species is included in the New Zealand fauna on the authority of Lillie, who records seeing two specimens in lat. S. $47^{\circ} 04^{\prime}$, long. E. $171^{\circ} 33^{\prime}$ (south-east of Nugget Point, Otago). The species is easily recognised on account of its peculiar coloration. It has been recorded in the Southern Ocean from Tasmania to Chile.

\section{Stenella.}

Stenella (§ Steno) Gray, 1866, Proc. Zool. Soc. 1866, p. 213 ; type, Steno attenuatus Gray. Prodelphinus Gervais, 1880, Ostéogr. Cét. p. 604 ; type, $P$. marginatus Duvernoy $(=P$. euphrosyne Gray).

I have adopted Stenella as the earliest valid name for this genus, passing over Sousa, proposed earlier on the same page, because it is probably only a variation of Susu (preoccupied by Lesson, 1828). It may also be added that Susu or Sousou is a Hindu word, and therefore the type of Sousa, if not hitherto fixed, should be the Indian species $S$. lentiginosus.

\section{STENella EUPHROSYNE.}

Delphinus euphrosyne Gray, 1846, Zool. 'Erebus' \& 'Terror,' p. 40, pl. 22. Clymenia novce zealandice (not Quoy \& Gaimard) Hector, 1873, Trans. N.Z. Inst. vol. v. p. 159, pl. 2 ; id. 1877, 1. c. vol. ix. pl. 11.

A large species, recorded from the North and South Atlantic. Its claim to be included in the New Zealand fauna rests on the following skull :-

Waikanae Coast.-Skull in Dominion Museum, Wellington. Described and figured by Hector. The proportions of this skull and the position of the nerve foramina agree with the type of D. euphrosyne as figured by Gray (Zool. 'Erebus' \& 'Terror,' pl. 22). Teeth $\frac{43+}{45}$. Length of skull $48 \mathrm{~cm}$., of rostrum $28.4 \mathrm{~cm}$. ; breadth of skull at squamosals, $23.3 \mathrm{~cm}$.; breadth of rostrum at base, $12 \mathrm{~cm}$. Pterygoids approximate to within $2 \mathrm{~mm}$. 
STENELLA PSEUDODELPHIS.

Delphinus pserdodelphis Schlegel, 1841, Abhandl. Gebiete Zool. Heft 1, p. 22. Clymenia attenuata Gray, Hector, 1885, Trans. N.Z. Inst. vol. xvii. p. 211.

This Dolphin has been recorded from the South Atlantic Ocean and Cape seas. Probably it should be united with S. malayanus Lesson (1826) and S. ficcenatus F. Cuvier (1836), and the distribution given as Atlantic, Indian, and Pacific Oceans. Its inclusion in the New Zealand fauna rests on a single skull. There is also in the Dominion Museum a mandible which I refer to this species. The tip is broken, but there are 36 alveoli present. Length of ramus $34 \mathrm{~cm}$., of symphysis $6 \mathrm{~cm}$.

Parapara.-Skull in Dominion Museum. Hector doubted this skull being obtained in the New Zealand area. It, however, bears the legend "Loc. Parapara. Hector 1879. Steno attenuatus Gray" written on the premaxillæ. The proportions of the skull and the contour of the premaxillæ are identical with the type of D. attenuatus figured by Gray (Zool. 'Erebus' \& 'Terror,' pl. 28), but there are high fronto-supraoccipital ridges (like the figure of $D$. doris in Gray's work). It is a large skull, and the high ridges may be a sign of age. Pterygoids in contact. Teeth missing, alveoli 39 , but end of rostrum not quite perfect. Length of skull $39.2 \mathrm{~cm}$., of rostrum $24 \mathrm{~cm}$; breadth of skull at squamosals $16.2 \mathrm{~cm}$., at orbits $14.7 \mathrm{~cm}$.; breadth of rostrum at base $9 \mathrm{~cm}$.

\section{Delphinus.}

Delphinus Linné, 1758, Syst. Nat. ed.10, p. 77; type, D. delphis Linné.

\section{DelPHiNus DELPHis.}

Delphinus delphis Linné, 1758, Syst. Nat. ed. 10, p. 77 (European seas). Delphinus novce zealandice Quoy \& Gaimard, 1830, Voy. 'Astrolabe,' Zool. vol. i. p. 149, pl. 28; Hutton, 1877, Trans. N.Z. Inst. vol. ix. p. 349. Delphinus forsteri Gray, Hector, 1872, Ann. Mag. Nat. Hist. ser. 4, vol. ix. p. 438; id. 1873 , Trans. N.Z. Inst. vol. v. p. 158 , pls. 2 , 3 ; id. 1874 , 1. c. vol. vi. p. 85 ; id. 1877 , l. c. vol. ix. pl. 11.

The Dolphin is found in all seas; it is common round the New Zealand coasts.

Bay of Islands. - Skull in Dominion Museum.

Hauraki Gulf.-I have seen a skull from Motutapu Island.

East Coast, North Island.- Specimen captured by the 'Astrolabe? off Tolaga Bay. Described by Quoy and Gaimard as the type of Delphinus novce zealandice.

Wanganui Beach.-Skull described by Hector (1873).

Cook Strait.-(a) Lyall Bay. Skeleton in Dominion Museum. Exterior described by Hector (1874). Teeth $\frac{48}{46}$. Vertebræ: C. 7 , D. 14 , L. 17 , Ca. $37=75$. Two cervicals fused. Ribs 14 , 
of which 3 are two-headed. Costal ribs 8, of which 5 articulate with the sternum. Sternum of one piece. Phalanges : 2, 9, 7, 2, 1 . (b) Porirua. Skull in Dominion Museum. Described by Hector (1872).

Lyttelton Harbour.-Skeleton in Canterbury Museum, from Governor's Bay, 1896. Vertebræ: C. 7, D. 15, L. 20, Ca. $33=75$. Ribs 15, of which 5 are two-headed, the last pair small, half the length of the 14 th. Costal ribs 8 , of which 4 appear to articulate directly with the sternum. Sternum of one piece, apparently of three fused segments. Pelvic bones curved, rod-like, about $8 \mathrm{~cm}$. long.

There is a skeleton from New Zealand in the British Museum. True (Bull. U.S. Nat. Mus. 36, p. xxxvi, 1889) gives the measurements of the skull.

\section{Tursiops.}

Tursiops Gervais, 1855, Hist. Nat. Mamm. vol. ii. p. 323 ; type, Delphinus tursio Fabricius ( $=D$. truncatus Montagu).

\section{Tursiops truncatus.}

Delphinus truncatus Montagu, 1815, Wern. Trans. vol. iii. pl. 5. Tursio metis Gray, Hector, 1873, Trans. N.Z. Inst. vol. v. p. 162 ; id. 1877 , l. c. vol. ix. p. 477 , pls. 11 , 12 ; Hutton, 1876 , l. c. vol. viii. p. 180. Tursiops tursio (Fabr.), Hector, 1885, l.c. vol. xvii. p. 210. Beluga kingii (not Gray) Hector, 1873, Ann. Mag. Nat. Hist. ser. 4, vol. xi. p. 105 ; id. 1873, Trans. N.Z. Inst. vol. v. p. 163. Delphinapterus leucas (not Pallas) Hector, 1885. 1. c. vol. xvii. p. 209.

The Cowfish appears to be widely distributed, having been recorded from localities as distant as the North Sea and New Zealand. In the latter place it has been recorded from both east and west coasts of the South Island.

Lyttelton Harbour.-Skeleton in Canterbury Museum, from Governors Bay, 1895. Teeth $\frac{21}{20}$. Vertebræ: C. 7, D. 13, L. 17, Ca. $27=64$. Two cervicals fused. Ribs 13 , with a vestige about $4 \mathrm{~cm}$. long on the right side only of a $14 \mathrm{th}$. Costal ribs 9 , of which the first is rather broad and thick, five articulate directly and four indirectly with the sternum. Sternum of 4 segments, the anterior curved upwards and notched in front and with a minute perforation in the centre.

Otago Harbour.-1913. Skull and cast in Otago Museum.

Dusky Sound.-( ) Skull in Otago Museum. 1898. (b) Skeleton in Otago Museum. Captured in Useless Bay, 10th May, 1875. Exterior and skull described by Hutton. Teeth $\frac{2}{2} \frac{3}{2}$. (c) Skeleton in Dominion Museum. Csptured in Useless Bay, 10th May, 1875, Described by Hector (1877). Teeth $\frac{2}{2} \frac{3}{3}$. The anterior pair, upper and lower small, not projecting above the alveoli. Vertebræ: C. 7, D. 12 , L. 17, Ca. $28=64$. Two cervicals fused. Ribs 12 , of which 4 are two-headed. Costal ribs 10, of which 5 articulate 
with the sternum. Sternum of 4 fused segments. (d) Skull in Dominion Museum, labelled "Dusky Bay, 6/1/73."

Locality not stated.-(a) Skeleton in Wanganui Museum. Teeth $\frac{2}{2}$. Vertebræ: C. 7, D. 12, L. 17, Ca. $22+=58+$. Ribs 12, of which 5 are two-headed. Two cervicals fused. (b) Skull (incomplete) in Dominion Museum. Labelled in Dr. Knox's handwriting "Beluga kingii Gray. The Australian Beluga. From Swainson Coll." This is merely an imperfect cranium; the whole of the rostrum and mandible are missing. It is from a young animal, as the frontal is quite separate and the cranial sutures are open. It appears to agree in all essential characters with the skulls of Tursiops truncatus in the Dominion Museum. The main point of difference which gives the present specimen a distinct appearance is the absence of a transverse supraoccipital ridge, but this is obvionsly due to age, and could not be expected to be pronounced in a young animal. This specimen was referred to under the name Beluga kingii by Hector (1873), and is responsible for the introduction into New Zealand literature of the "White Whale, Delphinapterus leucas," which finds a place in Hutton and Drummond's 'Animals of New Zealand,' but has been treated more cautiously by Waite, who omitted it altogether in his 'Guide to the Whales and Dolphins of New Zealand.'

\section{EXPLANATION OF THE PLATES.}

Plate I.

Neobalana marginata.

Fig. 1. Skull, lateral view.

2. Skull, superior view.

3. Skull, inferior view.

Plate II.

Cephalorhynchus hectori.

Fig. 1. Side view.

2. Inferior view.

Kogia breviceps.

Fig. 3. Specimen stranded at Wanganui, February 1909.

Plate III.

Mesoplodon bowdoini.

Fig. 1. Skull, superior view.

2. Skull, inferior view.

3. Skull, lateral view.

Plate IV.

Mesoplodon bowdoini.

Fig. 1. Mandible.

2. Left ramus of mandible.

3. Scapula. 


\section{$2 \mathrm{BHL}$ Biodiversity Heritage Library}

Oliver, W E B. 1922. "28. A review of the Cetacea of the New Zealand Seas I." Proceedings of the Zoological Society of London 1922, 557-585. https://doi.org/10.1111/j.1096-3642.1922.tb02157.x.

View This Item Online: https://www.biodiversitylibrary.org/item/100613

DOI: https://doi.org/10.1111/j.1096-3642.1922.tb02157.x

Permalink: https://www.biodiversitylibrary.org/partpdf/40992

\section{Holding Institution}

Smithsonian Libraries

\section{Sponsored by}

Biodiversity Heritage Library

\section{Copyright \& Reuse}

Copyright Status: Public domain. The BHL considers that this work is no longer under copyright protection.

This document was created from content at the Biodiversity Heritage Library, the world's largest open access digital library for biodiversity literature and archives. Visit BHL at https://www.biodiversitylibrary.org. 